\title{
O LULISMO E SUAS MANIFESTAÇÕES NO ELEITORADO ${ }^{1}$
}

Adriano Oliveira

\begin{abstract}
Resumo
O que é lulismo? Este artigo mostra que o lulismo é um fenômeno social visível no eleitorado brasileiro e sua manifestação se constata por meio de variáveis, dentre elas, avaliação da administração, confiança e merecimento. Inicialmente, apresenta-se o conceito de lulismo. Em seguida, mediante diversos surveys, mostra-se a manifestação do lulismo no eleitorado. Por meio da utilização dos clássicos determinantes do voto, além de considerar as circunstâncias políticas e econômicas que interferem na construção e desconstrução de fenômenos sociais, conclui-se que o lulismo: 1) existe independentemente da posição ideológica e dos estratos econômicos dos eleitores; 2) contribui para o fortalecimento do personalismo na política brasileira; e 3) é uma variável que influencia a escolha do eleitor.
\end{abstract}

Palavras-chaves: Comportamento Eleitoral; Determinantes do Voto; Escolha do Eleitor; Lulismo.

\begin{abstract}
What is lulism? This paper shows that the lulism is a social phenomenon visible in the Brazilian electorate and their manifestation is found to from variables, among these, assessment administration, and trust worthiness. Initially, this article presents the concept of lulism. It then shows, through various surveys, the lulism manifestation of the electorate. Through the use of classical determinants of the vote, and consider the circumstances and economic policies that interfere with the construction and deconstruction of social phenomena, this article concludes that the lulism: 1) exists independently of ideological position and economics stratas of voters; 2) contributes to the strengthening of personalism in Brazilian politics; and 3 ) is a variable that influences the choice of voter.
\end{abstract}

Keywords: Voting Behavior; Determinants of the Vote; Voter Choice; Lulism.

\section{Introdução}

As tentativas de Luís Inácio Lula da Silva de chegar à Presidência têm início em 1989 quando se candidata pela primeira vez a presidente ${ }^{2}$. Naquele ano, Lula foi derrotado por Fernando Collor de Melo no segundo turno. Lula teve $47 \%$ dos votos válidos nessa disputa e Fernando Collor obteve $53 \%$ dos votos válidos. Na eleição de 1994, Fernando Henrique Cardoso (FHC) do

\footnotetext{
${ }^{1}$ Agradeço ao Instituto de Pesquisa Maurício de Nassau (IPMN) pela contribuição a este artigo através da cooperação científica.

${ }^{2}$ Luís Inácio Lula da Silva tem origem social pobre. Exerceu atividade sindical e foi um dos fundadores do Partido dos Trabalhadores (PT). Em 1988 foi eleito deputado federal pelo estado de São Paulo.
} 
Partido da Social Democracia Brasileira (PSDB) venceu Lula no primeiro turno. O candidato do PSDB obteve $55,22 \%$ dos votos e o petista, $39,97 \%$. Em 1998, numa nova disputa entre PT e PSDB, FHC venceu a competição também no primeiro turno com $53 \%$ dos votos válidos contra $31,7 \%$ de Lula.

Luís Inácio Lula da Silva foi eleito presidente da República em 2002, após três seguidas tentativas frustradas. Nesse ano, Lula disputou a eleição para presidente contra José Serra (PSDB), candidato apoiado pelo então presidente FHC. O petista venceu a disputa no segundo turno com $46,44 \%$ (José Serra teve 23,19\%).

Em 2006, Lula foi reeleito com $48,6 \%$ dos votos válidos no segundo turno contra Geraldo Alckmin (PSDB), que teve 41,63\%. Em 2010, a candidata de Lula, Dilma Rousseff (PT), foi eleita presidente no segundo turno, obtendo $56 \%$ dos votos na disputa com José Serra, que teve $43,9 \%$ dos votos.

Em dezembro de 2005, Lula findou seu primeiro governo com 55\% de aprovação. Em 2010, finalizou o segundo mandato com $83 \%$ de aceitação (ACIMA, 2010) e 76\% dos brasileiros declararam confiar nele (IBOPE, 2010).

As duas vitórias seguidas em disputa presidencial, que propiciaram a Lula a conquista de capital eleitoral, a alta aprovação à sua administração, que foi crescente em dado período e apresentou regularidade, e o sucesso eleitoral de Dilma Rousseff suscitaram a expressão lulismo em diversos ambientes da sociedade brasileira, por exemplo, no espaço midiático ${ }^{3}$.

O que é lulismo? A resposta a essa indagação é o objetivo inicial deste trabalho. Temos a hipótese de que o lulismo é um fenômeno social verificável entre o comportamento dos eleitores. Sartori (1997) sugere que fenômenos sociais podem ser decifrados. Contudo, é preciso, antes de tudo, definir seu significado.

Quais as variáveis que revelam a manifestação do lulismo no eleitorado? O outro objetivo deste trabalho é apresentar as possíveis variáveis, as quais devem ser consideradas como hipóteses que possibilitam a identificação do lulismo. A contemplação desse objetivo é necessária, uma vez que é significativo identificar as variáveis que dão vida aos fenômenos sociais (VAN EVERA, 1997; ELSTER, 2006).

Este artigo se divide em quatro partes. Inicialmente, resgatamos da literatura os clássicos determinantes do voto que explicam a escolha do eleitor, também utilizados em outras seções deste artigo como referência teórica para definir o lulismo e mostrar sua manifestação. Em seguida, apresentamos o conceito de lulismo construído com a colaboração de Singer (2009).

Evidenciamos, na terceira parte do artigo, os indicadores que revelam a manifestação do lulismo no eleitorado. Para tal empreitada, consideramos a premissa empírica de que as circunstâncias políticas e econômicas importam

\footnotetext{
3 Em 2010, duas obras foram lançadas destacando o termo lulismo, quais sejam: Ricci (2010) e Pereira (2010).
} 
para explicar o desempenho dos governos e a avaliação do eleitorado em relação a estes (LAVAREDA, 2009). Nesse sentido, contextualizamos a era Lula, mostrando fatos que contribuíram para: 1) o enfraquecimento e o fortalecimento da avaliação da gestão do presidente Lula entre a opinião pública; 2) a oscilação do grau de confiança dos eleitores para com ele.

$\mathrm{Na}$ última seção do artigo, mostramos, por meio de survey e de modo detalhado, como o lulismo se manifesta no eleitorado pernambucano. As variáveis que serão apresentadas ampliam a visibilidade e a compreensão do fenômeno lulismo. Embora o survey tenha sido realizado num único estado brasileiro, Pernambuco, os dados apresentados lançam hipóteses de como o lulismo se manifesta em outras regiões do Brasil.

Concluímos afirmando que o lulismo é uma manifestação social advinda de parte do eleitorado brasileiro. Essa manifestação surge em razão do bem-estar econômico dos eleitores e diante da relação emocional que Lula construiu entre o eleitor. Por fim, asseveramos que o lulismo reforça as teses de que a imagem do candidato, a emoção que ela venha a propiciar ao eleitor, o bem-estar econômico do eleitorado e a aprovação à sua administração são variáveis que explicam a escolha do eleitor (CARREIRÃO, 2002; LOURENÇO, 2007; ALMEIDA, 2008; LAVAREDA, 2009; PIMENTEL JÚNIOR, 2010); além da tese de que a disputa eleitoral no Brasil é personalista e não partidária (CARREIRÃO, 2002; BORBA, 2005).

\section{Que determinantes do voto podem explicar o lulismo?}

A literatura que aborda os determinantes do voto no Brasil considera que a variável Avaliação da Administração contribui para explicar o sucesso e o insucesso eleitoral dos candidatos (ALMEIDA, 2008). Essa variável, entretanto, não deve ser reconhecida como suficiente para decifrar a conquista eleitoral do candidato. Ela é uma condição necessária para propiciar o sucesso eleitoral do competidor (LAVAREDA, 2009; OLIVEIRA e SANTOS, 2009).

A hipótese recorrente entre diversos autores é de que quanto maior a aprovação à administração do gestor, mais chances ele tem de ser reeleito voto retrospectivo (FIORINA, 1981). Ressaltamos que, para a literatura, a aprovação à administração do presidente da República se correlaciona com o desempenho da economia. Portanto, o bem-estar econômico do eleitor possibilita que ele aprove a gestão do presidente (FIORINA, 1981; ALMEIDA, 2008; OLIVEIRA e SANTOS, 2009; CARREIRÃO, 2009; LAVAREDA, 2009).

Considerando as eleições presidenciais de 1989, 1994 e 1998, Carreirão (2002) afirma que a imagem política, os atributos pessoais dos candidatos e o desempenho do governo em exercício, em particular na área econômica, são alguns fatores que constroem a escolha do eleitor. Para o autor, os atributos dados aos candidatos pelos eleitores possibilitam a identificação de qual é a imagem que estes têm dos competidores numa dada 
disputa eleitoral. Está presente, portanto, uma dimensão simbólica na relação do competidor com o eleitor (CARREIRÃO, 2002).

Pimentel Júnior (2007 e 2010) disserta sobre o papel das emoções na escolha do eleitor. ${ }^{4} \mathrm{O}$ autor constrói um diálogo entre razão, no caso, a escolha racional, e a emoção. De acordo com ele, baseado no modelo de Inteligência Afetiva (MARCUS, 2003), os eleitores têm entusiasmo e ansiedade ${ }^{5}$.

A hipótese de Pimentel Júnior (2010) é de que eleitores entusiasmados estão predispostos a votar em determinado candidato. Eleitores ansiosos estão em dúvida quanto à sua escolha eleitoral. Para o autor, a ansiedade do eleitor representa a reflexão quanto às vantagens e desvantagens de escolher algum candidato.

De acordo com Pimentel Júnior (2010), eventos ocorridos durante a campanha eleitoral podem interferir na predisposição do eleitor em votar no candidato. Como ele bem mostra por meio de análise quantitativa, o candidato bem avaliado pode vir a vencer a disputa no segundo turno em razão de que denúncias de corrupção criaram ansiedade nos eleitores e os levaram a repensar seu voto no primeiro turno.

Para o modelo de Inteligência Emocional, a avaliação dos governos, no caso o voto retrospectivo, não é puramente racional. "Eleitores não precisam estar conscientes das realizações do governo para compreender que a situação do país é melhor ou pior e nem verbalizar as razões disso" (PIMENTEL JÚNIOR, 2010, p. 528). Os eleitores podem avaliar o governo pela intuição afetiva. Ou seja: "Se a situação vai bem, sentimentos de entusiasmos são engendrados, enquanto que se a situação vai mal, o sentimento de ansiedade aumenta" (PIMENTEL JÚNIOR, 2010, p. 528).

Os indivíduos realizam suas escolhas baseados em crenças e expectativas do que poderá vir a ocorrer diante de determinada ação (ELSTER, 1997; AOKI, 2007). A variável Confiança, por exemplo, está associada à crença. Nesse caso, o eleitor acredita/confia que o candidato escolhido por ele atenderá às suas expectativas caso eleito. A crença em algum ator poderá advir da imagem que o eleitor tem daquele ator.

O eleitor, por exemplo, diante de um contexto em que vários candidatos são acusados de corrupção, poderá optar em votar naquele que tem sua imagem associada historicamente aos atributos honestidade e ética. Então, a imagem do candidato, que se forma por atributos (CARREIRÃO, 2002), possibilita a formação de crenças e cria expectativas entre o eleitor.

\footnotetext{
${ }^{4} \mathrm{Na}$ literatura internacional sobre emoções e escolha eleitoral, cf. Westen (2007).

5 O modelo de Inteligência Afetiva "advoga que as emoções possuem duas dimensões distintas: uma dimensão positiva, denominada entusiasmo, e outra negativa, chamada ansiedade. Tais emoções não possuem apenas uma função avaliativa, no sentido de que se o sentimento é negativo, as considerações cognitivas em relação ao objeto que engendra tal sentimento também serão, ou se positivo, que tenderemos a avaliá-lo melhor. A função das emoções dentro desse modelo é um pouco mais complexa: por um lado, regulam comportamentos rotineiros e, por outro, a atenção consciente" (PIMENTEL JÚNIOR, 2009, p. 519).
} 
Ressaltamos que as crenças e as expectativas do eleitor estão a depender do contexto em que ele se insere e dos seus valores. Os valores formam crenças e podem vir a condicionar a ação do indivíduo (BOUDON, 1995; ELSTER, 1997; AOKI, 2007; REZENDE, 2009).

Os valores, as crenças dos indivíduos e suas expectativas em relação a outrem possibilitam a construção de relações emocionais entre os atores. Por exemplo: os eleitores confiam no candidato $X$ em razão dos valores semelhantes, os quais provocam a crença e a expectativa de que ele atenderá às suas demandas. Ou melhor: o candidato não os decepcionará (REZENDE e COELHO, 2010) $)^{6}$.

\section{O que é o lulismo?}

Fenômenos sociais estão presentes na realidade e são construídos pela ação dos atores (BOUDON, 1995). Os fenômenos são objetos de estudo das ciências, e, claro, da ciência política, e podem ser compreendidos e explicados (DARTIGUES, 2008). O ato de compreender e explicar um fenômeno significa entender seu funcionamento, especificamente as relações de variáveis, as quais expressam mecanismos que Ihe dão vida (VAN EVERA, 1997; ELSTER, 2006).

As ações sociais de um ator podem fazer um fenômeno social surgir na sociedade. É possível verificar as manifestações do fenômeno na sociedade por meio das ações dos indivíduos. Por exemplo: a opinião dos eleitores sobre determinado ator pode expressar a manifestação de um fenômeno social ${ }^{7}$.

Nossa hipótese é de que existe no Brasil o fenômeno social lulismo. Singer (2009) sugere que o lulismo representa uma nova configuração ideológica que mistura elementos de esquerda e direita. Para o autor, as raízes do lulismo estão na retórica da estabilidade econômica e da ação distributiva do Estado.

Interpretamos, inicialmente, a argumentação de Singer (2009) do seguinte modo: o lulismo é um fenômeno social que une indivíduos com preferências eleitorais semelhantes, as quais são encontradas e correspondidas nos diversos espectros ideológicos clássicos - esquerda, direita, centro, etc. Entretanto, Singer (2009, p. 84) afirma que "a emergência do lulismo expressa um fenômeno de uma fração de classe, que,

\footnotetext{
${ }^{6}$ Pimentel Júnior (2010) e Rezende e Coelho (2010) sugerem que a compreensão da emoção se circunscreve à seguinte indagação: o que emociona o indivíduo? Nesse sentido, sentimentos como raiva e medo, e expressões eu confio nele, ele merece e ele me traz esperança representam atitudes emocionais.

7 "O primeiro princípio fundamental da sociologia da ação consiste em levar a sério o fato de que todo fenômeno social, qualquer que seja, é sempre o resultado de ações, de atitudes, de convicções, e em geral de comportamentos individuais. O segundo princípio, que completa o primeiro, afirma que o sociólogo que pretende explicar um fenômeno social deve procurar o sentido dos comportamentos individuais que estão em sua origem" (BOUDON, 1995, p. 28, grifo do autor).
} 
embora majoritária, não consegue construir desde baixo as suas próprias formas de organização".

Nesse sentido, observamos que existem dois aspectos que caracterizam a definição dada por Singer (2009) ao fenômeno social lulismo, quais sejam: ausência de identificação ideológica e estratificação econômica. Portanto, para Singer, o lulismo está cima das posições ideológicas; e o acesso do povo aos benefícios da economia advindos da estabilidade econômica e de políticas sociais, como o Bolsa-Família, fizeram com que o presidente Lula fosse sustentado eleitoralmente pela "base subproletária" (SINGER, 2009, p. 101) $)^{8}$.

Temos a hipótese, considerando o eleitorado brasileiro, de que o Iulismo significa uma manifestação política por parte dos eleitores em relação ao presidente Luís Inácio Lula da Silva, verificável nos altos índices de aprovação e confiança dos eleitores na sua administração e pessoa.

Desse modo, a manifestação dos eleitores em relação ao ator Lula se identifica pelas seguintes variáveis: aprovação à administração e índice de confiança. O lulismo é visível entre os eleitores mesmo em momentos em que não há competição eleitoral iminente ou nas disputas eleitorais.

Entretanto, em virtude da presença de outras variáveis, construímos outra hipótese, que é mais complexa. Nesse sentido, o fenômeno social lulismo em Pernambuco se manifesta mediante as seguintes variáveis/indicadores: aprovação à administração, reconhecimento do eleitor, merecimento e contribuição para a melhoria da vida dos brasileiros.

Por fim, observamos, de modo geral, que o fenômeno social lulismo tem as seguintes características, as quais, salientamos, devem ser reconhecidas neste momento como hipóteses:

a) expressa-se por meio da admiração que os eleitores têm pela gestão do presidente Lula e a confiança que nele depositam;

b) tem um caráter emocional. Os eleitores admiram a imagem do presidente Lula e nele confiam;

c) surgiu, em âmbito nacional, nas eleições de 2006; no primeiro mandato do presidente Lula, o lulismo estava em processo de construção, embora, em razão de circunstâncias políticas, tenha sofrido um substancial enfraquecimento no seu crescimento em meados de 2005;

d) existe, em Pernambuco, independentemente da posição ideológica e do estrato econômico do eleitor;

e) é um fenômeno social que, em Pernambuco, reforça o personalismo na política e enfraquece os partidos políticos;

f) deve ser considerado como um novo determinante do voto para explicar a escolha do eleitor.

\footnotetext{
8 Subproletários são os que "oferecem a sua força de trabalho no mercado sem encontrar quem esteja disposto a adquiri-la por um preço que assegure sua reprodução em condições normais. [...] Empregados domésticos, assalariados de pequenos produtores e trabalhadores destituídos das condições mínimas de participação na luta de classes" (SINGER apud SINGER, 2009, p. 2223).
} 


\section{A construção e a manifestação do lulismo}

Considerando os dois mandatos presidenciais, a administração do presidente Luís Inácio Lula da Silva teve aprovação crescente, conquistou seus maiores índices no segundo mandato. No primeiro mandato, a média da aprovação à administração do presidente Lula foi de $42,1 \%$ de ótimo/bom. No segundo mandato, a média foi de $68,1 \%$ (Figura 1 ).

Figura 1 - Gráfico representativo da administração do presidente Lula 2003-2010 (\%)

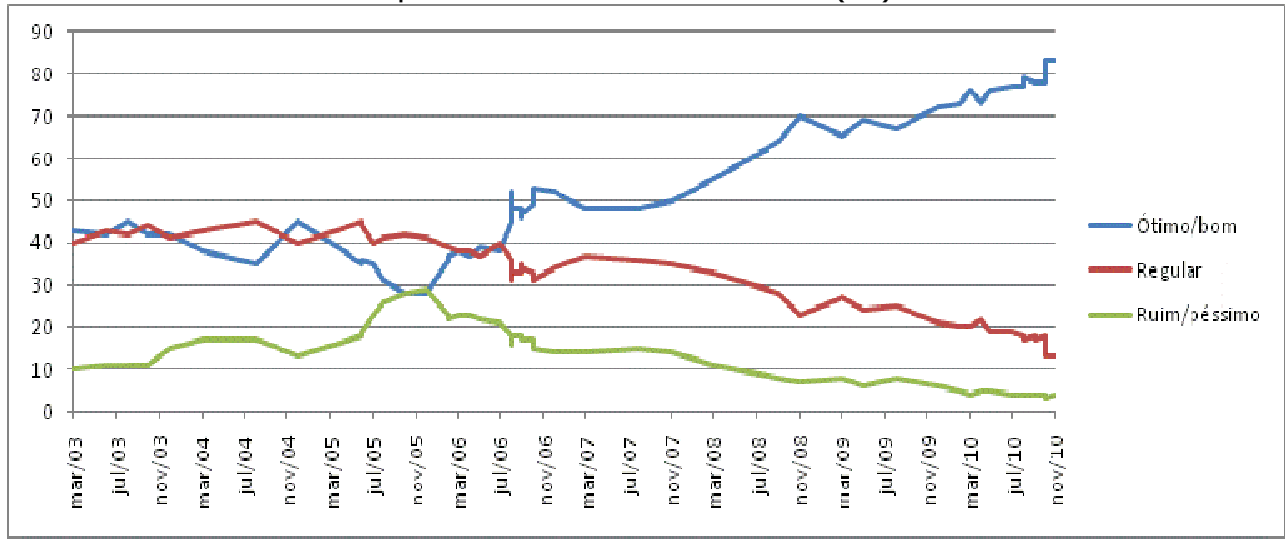

Fonte: elaborado pelo autor com base em Instituto Datafolha9.

Qual é a razão da diferença entre as médias de aprovação? Circunstâncias econômicas e políticas contribuem ou condicionam a aprovação à administração dos gestores (LAVAREDA, 2009). Desse modo, temos a hipótese de que, mesmo diante de circunstâncias econômicas satisfatórias, o eleitor, em virtude de circunstâncias políticas, pode vir a olhar de modo diferente para a administração presidencial (PIMENTEL JÚNIOR, 2010).

Por conseguinte, diante da possível relação causal sugerida pela literatura entre Bem estareconômico e Aprovação à administração, é possível que uma variável interveniente surja e enfraqueça tal relação. Essa variável advém, então, das circunstâncias políticas.

No primeiro mandato do presidente Lula, o então deputado federal Roberto Jefferson, do Partido Trabalhista Brasileiro (PTB), em junho de 2005, fez a denúncia de que o publicitário Marcos Valério Fernandes de Souza, com o tesoureiro do PT, Delúbio Soares, pagava mensalmente a deputados para que eles votassem favoravelmente na Câmara dos Deputados os pleitos do governo do PT. Esse episódio ficou conhecido como Escândalo do Mensalão,

9 Blog de Fernando Rodrigues. Disponível em: < http://noticias.uol.com.br/politica/psquisas/>. Acesso em: 28 fev. 2011. 


\section{ARTIGOS}

expressão utilizada pelo deputado petebista ao se referir às mensalidades pagas.

Definimos o mensalão, com base em informações advindas de Pereira (2010), como uma prática política, supostamente presente no governo Lula, caracterizada pela distribuição de recursos mensais por parte de agentes do PT a diversos deputados federais. Esses recursos serviam como incentivo para que parlamentares entrassem ou permanecessem na coalizão partidária do governo Lula.

A denúncia de Jefferson causou diversas modificações no governo de Lula, dentre elas, a saída do ministro chefe José Dirceu da Casa Civil; a abertura de espaço na coalizão partidária para o PMDB, passando o partido a ocupar diversos ministérios; e a confissão (admissão) do presidente Lula de que o PT utilizava caixa dois nas campanhas eleitorais (EPAMINONDAS NETO, 2005; PEREIRA, 2010).

O escândalo do mensalão causou a queda na popularidade do presidente Lula, além da perda de confiança por parte do eleitorado em relação à sua pessoa (cf. Figuras 1 e 2). Naquele momento os atores políticos, em particular os do PSDB, cogitaram o impeachment do presidente da República, a possibilidade de que ele não fosse candidato à reeleição na disputa eleitoral de 2006 e a previsível vitória da oposição nessa eleição (PEREIRA, 2010).

A média de aprovação (ótimo/bom) à administração do presidente Lula antes do mensalão era de $40,7 \%$, e a média de confiança na pessoa do presidente correspondia a 64,4\%. De junho de 2005, mês em que surgiu o escândalo, até dezembro do mesmo ano, a média de aprovação foi de $31,6 \%$ e a de confiança, $47,5 \%$. 
Figura 2 - Gráfico representativo do índice de confiança dos eleitores no presidente Lula 2003-2010 (\%)

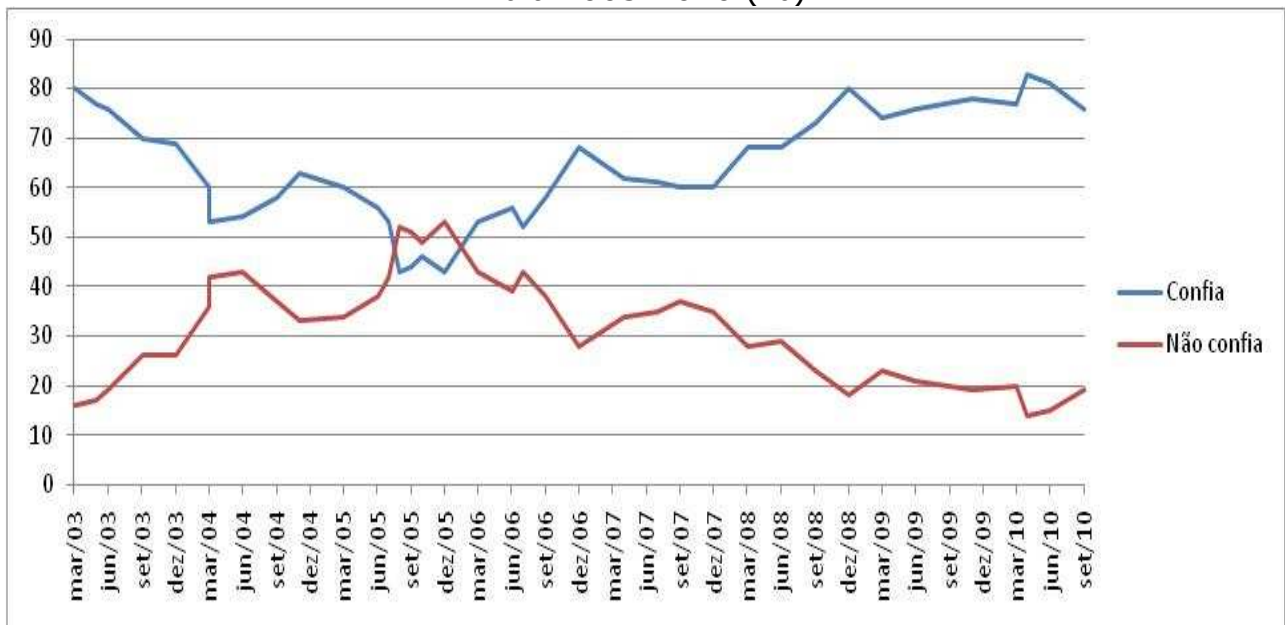

Fonte: elaborado pelo autor com base em Instituto Ibope ${ }^{10}$.

Em fevereiro de 2006, a aprovação ao presidente Lula voltou a crescer, e a média de aprovação ao seu governo, considerando o período de fevereiro a dezembro de 2006, foi de 45,2\%. Em março de 2006, a confiança no presidente Lula cresceu em relação a dezembro de 2005 , subiu de $43 \%$ para $53 \%$. De março a dezembro de 2006, a confiança média em Lula foi de $57,4 \%$.

Pereira (2010) mostra que em dezembro de 2005 o debate em torno do mensalão começou a enfraquecer na imprensa e no Congresso Nacional. Dentre as variadas razões para esse enfraquecimento estão: a cassação do mandato do deputado federal José Dirceu pela Câmara dos Deputados ${ }^{11}$; 0 fim da CPI do Mensalão ${ }^{12}$; e a aproximação política com o PMDB no Congresso, que motivou a troca de dez ministros no segundo semestre de 2005.

O arrefecimento de fatos políticos que interferiram negativamente na imagem da gestão de Lula no segundo semestre de 2005 e a variação positiva

\footnotetext{
10 Blog de Fernando Rodrigues. Disponível em: <http://noticias.uol.com.br/politica/psquisas/>. Acesso em: 28 fev. 2011.

11 José Dirceu chegou a ser considerado o ator político mais influente do governo Lula. Entretanto, Waldomiro Diniz, homem da sua confiança, foi exonerado do cargo de subchefe de Assuntos Parlamentares da Presidência da República em 2004, após denúncias de que negociava com bicheiros o favorecimento em concorrências. Em troca, recebia propinas e contribuições para campanhas eleitorais. José Dirceu, em junho de 2005, deixou o ministério da Casa Civil, e em dezembro, foi cassado pela Câmara dos Deputados.

12 A Comissão Parlamentar de Inquérito (CPI) foi criada no âmbito do Congresso Nacional em 20 de julho de 2005, para apurar o escândalo do mensalão. Foi encerrada sem a aprovação do relatório final em novembro de 2005.
} 
do PIB (Produto Interno Bruto) nos diversos quadrimestres de 2006, com exceção do segundo quadrimestre desse mesmo ano, podem ter contribuído para a recuperação da imagem da administração do presidente Lula, seu crescimento nas pesquisas de intenção de voto $^{13}$ e sua reeleição - cf. Figura 3 (CARREIRÃO, 2009) ${ }^{14}$.

Figura 3 - Gráfico representativo do desempenho do governo Lula: avaliação da administração, intenção de voto e variação do PIB 2005-2006 (\%)

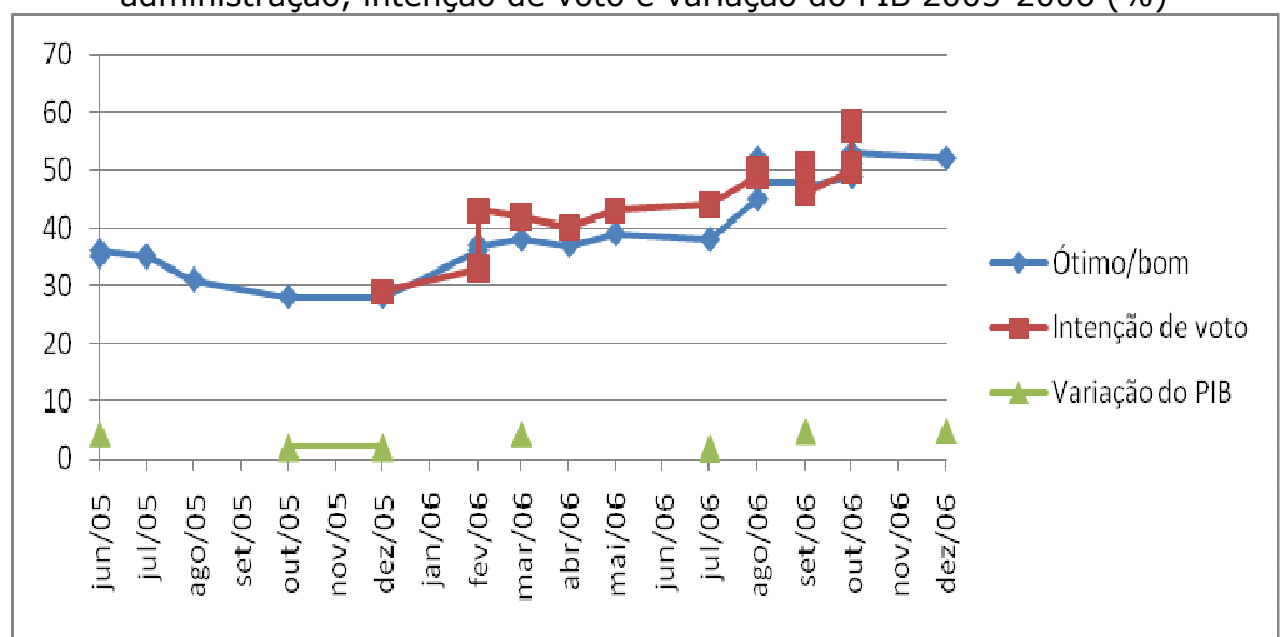

Fonte: elaborado pelo autor com base em Instituto Datafolha ${ }^{15}$ e IPEA.

O segundo mandato do governo Lula foi marcado pela ausência de escândalos políticos da proporção do mensalão. Entretanto, em 2008, uma forte crise econômica mundial, originada nos Estados Unidos, afetou negativamente o crescimento da economia brasileira ${ }^{16}$.

Com o objetivo de amainar as consequências da crise econômica, o presidente Lula cortou impostos de produtos industrializados, oferta de crédito a empresas e ao consumidor e exaltou a população a continuar consumindo.

\footnotetext{
13 Observa-se na Figura 3 a contínua evolução da intenção de voto do presidente Luís Inácio Lula da Silva.

14 "Resumiendo: La elección tuvo, en gran parte, un carácter de plebiscito (a favor o contra la continuidad de Lula). La evaluación predominantemente positiva de los resultados de las políticas econômica y social del gobierno de Lula (en especial entre los segmentos más pobres) acabo por predominar sobre el desgaste traído por las denuncias de corrupción del gobierno. La elección de Alckmin (y no Serra) como candidato del PSDB, la falta de una propuesta alternativa que entusiasmasse al electorado y una mejor campaña del presidente Lula (en relacción a Alckmin) reforzaron la ventaja previa del presidente" (CARREIRÃO, 2009, p. 47).

15 Blog de Fernando Rodrigues. Disponível em: <http://noticias.uol.com.br/politica/psquisas/>. Acesso em: 28 fev. 2011.

${ }^{16}$ A crise financeira mundial surgiu em 2008, tendo seu ápice em 2009. Ela decorreu em razão da falência do tradicional banco de investimento americano Lehman Brothers, fundado em 1850.
} 
As ações do governo Lula foram elogiadas por vários analistas econômicos. No terceiro quadrimestre de 2009, a economia brasileira retomou o crescimento (Figura 4).

Figura 4 - Gráfico representativo da variação do Produto Interno Bruto no governo Lula 2002-2010

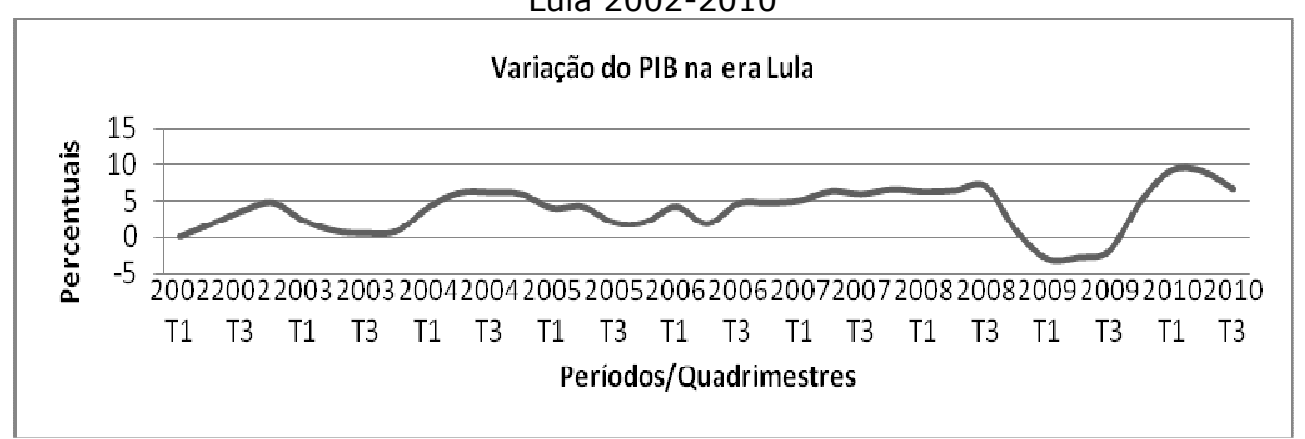

Fonte: elaborado pelo autor com base em IPEA.

Em setembro de 2008, a avaliação da administração do presidente Lula começou a alcançar índices acima de $60 \%$. Em 2009, período em que a crise econômica mundial contribuiu para que 0 PIB brasileiro variasse negativamente, a gestão de Lula obteve os seguintes percentuais de aprovação: março, 65\%; maio, 69\%; agosto, 67; e dezembro, $72 \%$. O governo Lula chegou ao fim do seu mandato com $83 \%$ de aprovação (ACIMA, 2010) $)^{17}$.

Verificamos que, em dezembro de 2006, a confiança no presidente Lula alcançou $68 \%$. Esse indicador, durante o segundo mandato do presidente Lula, não decresceu para menos de $60 \%$. Em setembro de 2010 , a confiança no presidente Lula alcançou $76 \%$. No período da crise econômica, ano base 2009, a confiança no presidente da República obteve $74 \%$ em março; junho, $76 \%$ e novembro, $78 \%$ (IBOPE, 2010).

Nas eleições de 2010, o presidente Lula apoiou Dilma Rousseff para sucedê-lo. Ele se dedicou integralmente à campanha da candidata petista. Atores da imprensa chegaram mesmo a afirmar que Lula era o candidato, e não Dilma. O principal candidato opositor de Dilma Rousseff, José Serra (PSDB), optou por não realizar oposição radical ao presidente Lula, chegando a afirmar que Lula estava acima do bem e do mal (LACERDA, 2010).

Com base nas variáveis Avaliação da Administração e Confiança, mostramos de que modo o fenômeno social lulismo se manifesta no eleitorado brasileiro. Como já exposto por Carreirão (2009), o bem-estar econômico e a

\footnotetext{
17 "Entre os brasileiros que estudaram até o ensino fundamental, a popularidade de Lula chega a $86 \%$, mas cai a $74 \%$ entre a população que tem nível superior de ensino. Entre as regiões do país, o petista atinge a maior popularidade no Nordeste ( $88 \%)$ e Norte e Centro-Oeste (87\%). No Sul, o índice [...] é de 77\%, e fica em 79\% no Sudeste" (ACIMA, 2010, s./p.).
} 
ausência de escândalos que encontrassem forte ressonância nos eleitores favoreceram o crescimento dos índices referentes às variáveis Avaliação da Administração e Confiança. Além disso, é perceptível uma relação emocional entre o presidente Lula e os eleitores, expressa pela variável confiança. Nesse sentido, constatamos, apesar da crise econômica, que um percentual elevado de eleitores continuou a confiar no presidente Lula.

\section{O lulismo em Pernambuco}

Esta parte do artigo mostra de forma detalhada a manifestação do lulismo entre os eleitores. Por meio de survey realizado pelo Instituto de Pesquisa Maurício de Nassau no estado de Pernambuco, procuramos comprovar as diversas hipóteses apresentadas neste artigo ${ }^{18}$.

Para $89,9 \%$ dos eleitores pernambucanos, Luís Inácio Lula da Silva foi o melhor presidente da História do Brasil. Para 1,9\%, FHC, seu antecessor, foi o melhor. Getúlio Vargas obteve o percentual de 1\%. Ressaltamos que 93,1\% dos eleitores consideram que Lula foi o presidente que mais fez por Pernambuco. Apontaram FHC $0,8 \%$ dos eleitores. Esses dados revelam a admiração dos eleitores pernambucanos pelo presidente Lula.

Figura 5 - Gráfico demonstrativo de quem foi o melhor presidente do Brasil. Para você, qual foi o melhor presidente do Brasil? (\%)

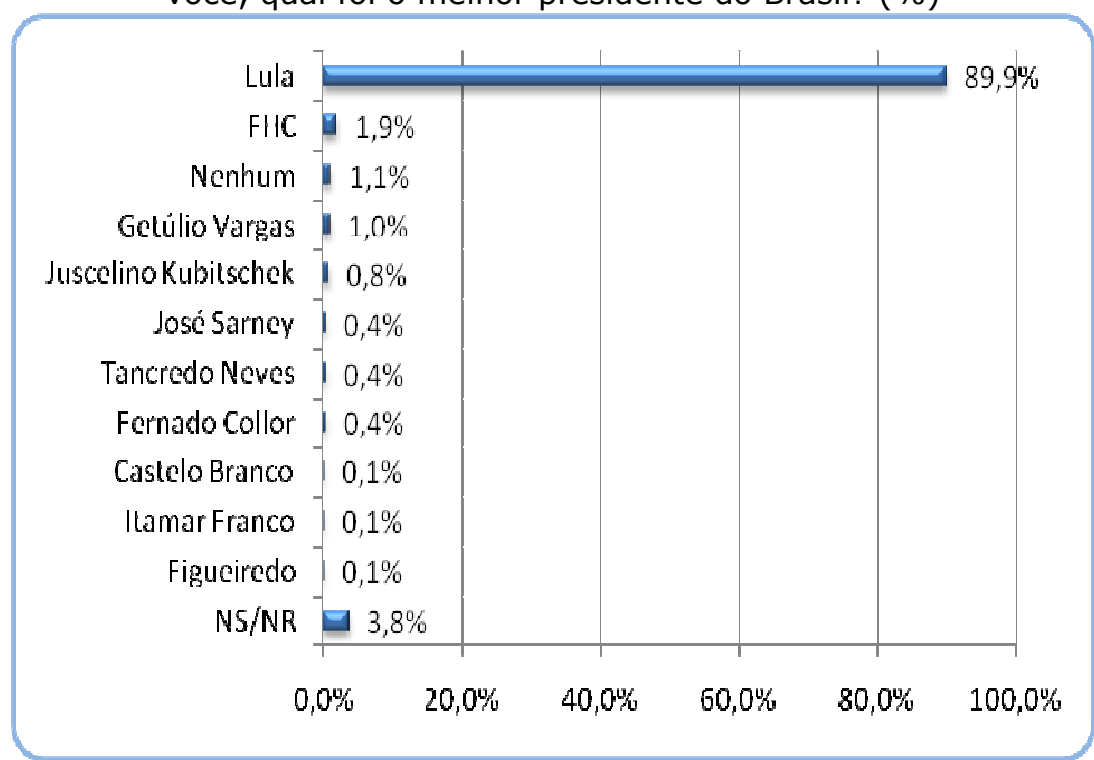

Fonte: elaborado pelo autor com base em IPMN (2010).

\footnotetext{
18 Pesquisa realizada no estado de Pernambuco no período de 17 a 18 de novembro de 2010 . Foram entrevistados 2.481 indivíduos com 16 anos de idade ou mais. A margem de erro da pesquisa é de $2,5 \%$.
} 
Em Pernambuco, $82 \%$ dos eleitores já votaram no presidente Lula. Esse percentual é semelhante em todos os estratos econômicos e em todas as regiões pesquisadas do estado. Aprovam a administração do presidente Lula $94 \%$ dos eleitores pernambucanos (bom/ótimo). Entre os eleitores que recebem mais de 5 salários mínimos, os que aprovam a administração do presidente Lula são $95 \%$.

No segmento dos eleitores que ganham até 1 salário mínimo, a aprovação é de $94 \%$ (ótimo/bom); dentre os que recebem de 1 a 2 salários mínimos, aprovam a gestão de Lula 95\%; e 91\% dos eleitores que têm renda entre 2 e 5 salários mínimos consideram a administração do presidente Lula como boa/ótima.

Tabela 1 - Avaliação da administração do presidente Lula (\%)

\begin{tabular}{|c|c|c|c|c|c|c|c|c|c|c|c|c|c|}
\hline & & & & & & dade & & & & Gra & u de ins & rução & \\
\hline & Total & Mas. & Fem. & $\begin{array}{c}16- \\
24\end{array}$ & $\begin{array}{c}25- \\
34\end{array}$ & $\begin{array}{c}35- \\
44\end{array}$ & $\begin{array}{c}45- \\
59\end{array}$ & $\begin{array}{c}60 \\
\text { ou } \\
+\end{array}$ & $\begin{array}{c}\text { Até } \\
3^{a} . \\
\text { série. } \\
\text { fund. }\end{array}$ & $\begin{array}{c}4^{a} \text { a } \\
7^{a} \\
\text { série } \\
\text { fund. }\end{array}$ & $\begin{array}{l}\text { Fund. } \\
\text { compl. }\end{array}$ & $\begin{array}{l}\text { Médio } \\
\text { compl. }\end{array}$ & $\begin{array}{l}\text { Super. } \\
\text { Compl. }\end{array}$ \\
\hline Base & 100 & 47 & 53 & 20 & 25 & 21 & 20 & 15 & 18 & 23 & 24 & 32 & 4 \\
\hline Ótima & 57 & 56 & 58 & 54 & 56 & 59 & 59 & 58 & 54 & 60 & 60 & 54 & 59 \\
\hline Boa & 37 & 38 & 35 & 40 & 38 & 35 & 34 & 34 & 41 & 35 & 36 & 37 & 30 \\
\hline Regular & 6 & 6 & 7 & 6 & 5 & 6 & 7 & 7 & 5 & 5 & 4 & 9 & 11 \\
\hline $\begin{array}{c}\text { Ruim/ } \\
\text { Péssima }\end{array}$ & 0 & 0 & 0 & 0 & 0 & 0 & 0 & 0 & 0 & 0 & 0 & 0 & 0 \\
\hline
\end{tabular}

Tabela 2 - Avaliação da administração do presidente Lula (\%)

\begin{tabular}{|c|c|c|c|c|c|c|c|c|c|c|c|c|}
\hline \multirow{2}{*}{\multicolumn{2}{|c|}{ Total }} & \multicolumn{5}{|c|}{ Renda } & \multicolumn{6}{|c|}{ Regiäo de desenvolvimento } \\
\hline & & & & & & & & & & & & \\
\hline Base & 100 & 58 & 26 & 7 & 2 & 8 & 18 & 24 & 15 & 24 & 10 & 10 \\
\hline Ótima & 57 & 57 & 60 & 60 & 59 & 48 & 57 & 54 & 61 & 60 & 53 & 56 \\
\hline Boa & 37 & 37 & 35 & 31 & 36 & 44 & 34 & 40 & 30 & 36 & 42 & 37 \\
\hline Regular & 6 & 6 & 5 & 8 & 5 & 8 & 9 & 6 & 9 & 4 & 5 & 6 \\
\hline $\begin{array}{l}\text { Ruim/ } \\
\text { Péssima }\end{array}$ & 0 & 0 & 0 & 0 & 0 & 0 & 0 & 0 & 0 & 0 & 0 & 0 \\
\hline
\end{tabular}

Qual é o partido do presidente Lula? Dentre os eleitores, $88,4 \%$ sabem que o presidente Lula pertence aos quadros do PT, e 52,9\% declaram que o PT é o partido que eles mais admiram na política brasileira. Para $57,3 \%$ dos inquiridos, o presidente Lula tem uma imagem boa ou é uma ótima pessoa. Além disso, a pesquisa revela outros qualificativos atribuídos à imagem de Lula, quais sejam: trabalha pelos pobres $(5,3 \%)$, pessoa justa $(4,3 \%)$, um vencedor $(3,2 \%)$, humilde $(2,2 \%)$. 
Figura 6 - Gráfico representativo da imagem do presidente Lula Qual é a imagem que você tem do presidente Lula? (\%)

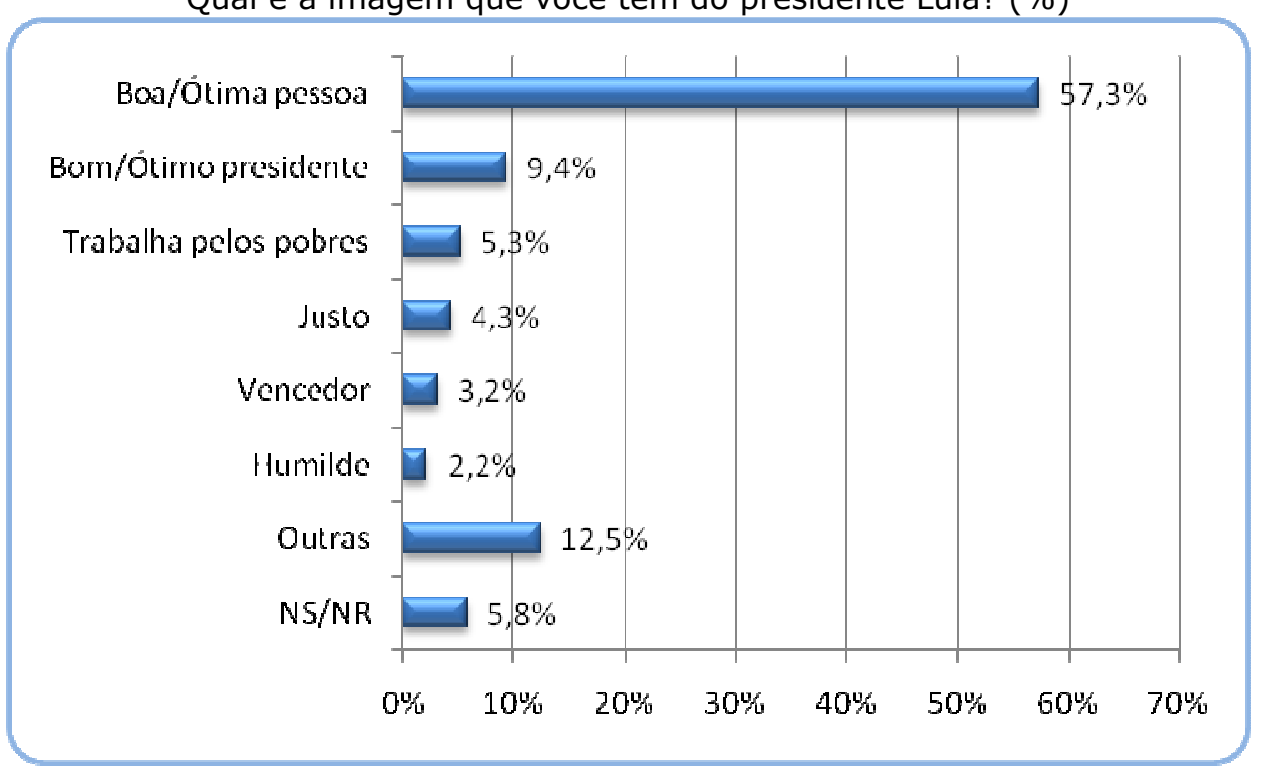

Fonte: elaborado pelo autor com base em IPMN (2010).

Para $91 \%$ dos entrevistados, o presidente Lula merece ser candidato novamente a presidente da República. Nos segmentos econômicos dos que recebem até 2 salários mínimos, os percentuais são semelhantes, ou seja, $92 \%$ afirmam que o presidente Lula merece ser candidato a presidente da República em 2014. Porém, a partir do estrato dos eleitores que ganham acima de 2 salários mínimos, constatamos um decréscimo.

Entre os eleitores que têm renda acima de 2 salários mínimos até 5 salários, 86\% afirmam que Lula merece ser candidato em 2014. No estrato dos que recebem mais de 5 salários mínimos, $77 \%$ frisam que o presidente merece ser candidato em 2014. Apesar da variação quando consideramos os estratos econômicos, os percentuais dos que afirmam que Lula merece ser candidato em 2014 estão acima de 75\%. 
Tabela 3 - Opinião sobre Lula ser candidato novamente a presidente da República em $2014^{19}$ (\%)

\begin{tabular}{|c|c|c|c|c|c|c|c|c|c|c|c|c|c|}
\hline \multicolumn{2}{|c|}{ Total } & \multicolumn{2}{|c|}{ Sexo } & \multicolumn{5}{|c|}{ Idade } & \multicolumn{5}{|c|}{ Grau de instrução } \\
\hline & & Mas. & Fem. & $\begin{array}{c}16- \\
24 \\
\text { anos }\end{array}$ & $\begin{array}{c}25- \\
34 \\
\text { anos }\end{array}$ & $\begin{array}{c}35- \\
44 \\
\text { anos }\end{array}$ & $\begin{array}{c}45- \\
59 \\
\text { anos }\end{array}$ & $\begin{array}{l}60 \\
\text { ou } \\
+\end{array}$ & $\begin{array}{l}\text { Até a } \\
3^{a} \text { sér. } \\
\text { fund. }\end{array}$ & $\begin{array}{c}4^{\mathrm{a}} \text { a } \\
7^{\mathrm{a}} \\
\text { série } \\
\text { fund. }\end{array}$ & $\begin{array}{l}\text { Fund. } \\
\text { compl. }\end{array}$ & $\begin{array}{l}\text { Médio } \\
\text { compl. }\end{array}$ & $\begin{array}{l}\text { Super. } \\
\text { Compl. }\end{array}$ \\
\hline Base & 100 & 47 & 53 & 20 & 25 & 21 & 20 & 15 & 18 & 23 & 24 & 32 & 4 \\
\hline Sim & 91 & 92 & 90 & 93 & 91 & 91 & 90 & 87 & 92 & 93 & 93 & 87 & 82 \\
\hline Não & 6 & 6 & 6 & 5 & 6 & 6 & 7 & 7 & 4 & 4 & 5 & 10 & 9 \\
\hline NS/NR & 3 & 2 & 4 & 2 & 3 & 3 & 3 & 5 & 4 & 3 & 2 & 3 & 10 \\
\hline
\end{tabular}

Fonte: elaborado pelo autor com base em IPMN (2010).

Tabela 4 - Opinião sobre Lula ser candidato novamente a presidente da República em 2014 (\%)

\begin{tabular}{|c|c|c|c|c|c|c|c|c|c|c|c|c|}
\hline \multicolumn{2}{|c|}{ Total } & \multicolumn{5}{|c|}{ Renda } & \multicolumn{6}{|c|}{ Regiăo de desenvolvimento } \\
\hline & & $\begin{array}{l}\text { Até } \\
1 \\
\text { SM }\end{array}$ & $\begin{array}{l}\text { Acima } \\
\text { de } 1 \text { a } \\
2 \text { SM }\end{array}$ & $\begin{array}{l}\text { Acima } \\
\text { de } 2 \text { a } \\
5 \text { SM }\end{array}$ & $\begin{array}{l}\text { Acima } \\
\text { de } 5 \\
\text { SM }\end{array}$ & NS/NR & Recife & $\begin{array}{c}\text { RMR } \\
\text { exceto } \\
\text { Recife }\end{array}$ & $\begin{array}{l}\text { Zona } \\
\text { da } \\
\text { mata }\end{array}$ & Agreste & Sertão & $\begin{array}{l}\text { Reg. São } \\
\text { Francisco }\end{array}$ \\
\hline Base & 100 & 58 & 26 & 7 & 2 & 8 & 18 & 24 & 15 & 24 & 10 & 10 \\
\hline Sim & 91 & 92 & 92 & 86 & 77 & 88 & 90 & 87 & 91 & 92 & 95 & 93 \\
\hline Não & 6 & 6 & 6 & 9 & 13 & 6 & 7 & 8 & 6 & 7 & 4 & 3 \\
\hline NS/NR & 3 & 3 & 2 & 4 & 10 & 5 & 3 & 5 & 3 & 1 & 1 & 4 \\
\hline
\end{tabular}

Fonte: elaborado pelo autor com base em IPMN (2010).

Merecer pode vir a expressar o desejo do eleitor. Nesse sentido, adquirimos condições de afirmar que $91 \%$ dos eleitores pernambucanos desejam que o presidente Lula seja candidato na eleição presidencial de 2014. Ressaltamos que $89 \%$ dos eleitores pretendem votar em Lula em 2014 caso ele seja candidato novamente.

Para $66 \%$ dos pernambucanos, o presidente Lula melhorou a vida de todos os brasileiros - os dados não variam quando observamos os estratos econômicos, porém $28 \%$ afirmam que Lula melhorou a vida apenas dos mais pobres. Esse percentual sugere a razão de que 5,3\% dos eleitores qualificarem a imagem do presidente Lula como um ator que trabalha para os mais pobres e 4,3\% o considerarem justo. Destacamos, contudo, que nesse quesito, observamos que 33\% dos eleitores que ganham mais de 5 salários mínimos afirmam que Lula melhorou sim a vida dos brasileiros, mas apenas dos mais pobres.

\footnotetext{
19 Pergunta: O presidente Lula findará o mandato presidencial este ano. Em sua opinião, ele merece ser candidato novamente a presidente do Brasil nas eleições presidenciais de 2014 ?
}

REVISTA DEBATES, Porto Alegre, v.5, n.1, p. 115-138, jan.-jun. 2011. 
Tabela 5 - Opinião sobre o presidente Lula haver melhorado a vida dos brasileiros ${ }^{20}(\%)$

\begin{tabular}{|c|c|c|c|c|c|c|c|c|c|c|c|c|c|}
\hline & & \multicolumn{2}{|c|}{ Sexo } & \multicolumn{5}{|c|}{ Idade } & \multicolumn{5}{|c|}{ Grau de instruçáo } \\
\hline & Total & Mas. & Fem. & $\begin{array}{c}16- \\
24 \\
\text { anos }\end{array}$ & $\begin{array}{c}25- \\
34 \\
\text { anos }\end{array}$ & $\begin{array}{c}35- \\
44 \\
\text { anos }\end{array}$ & $\begin{array}{c}45- \\
59 \\
\text { anos }\end{array}$ & $\begin{array}{l}60 \\
\text { ou } \\
+\end{array}$ & $\begin{array}{l}\text { Até a } \\
3^{a} \\
\text { sér. } \\
\text { fund. }\end{array}$ & $\begin{array}{c}4^{a} \text { a } \\
7^{a} \\
\text { sér. } \\
\text { fund. }\end{array}$ & $\begin{array}{l}\text { Fund. } \\
\text { compl. }\end{array}$ & $\begin{array}{l}\text { Médio } \\
\text { compl. }\end{array}$ & $\begin{array}{l}\text { Super. } \\
\text { compl. }\end{array}$ \\
\hline Base & 100 & 47 & 53 & 20 & 25 & 21 & 20 & 15 & 18 & 23 & 24 & 32 & 4 \\
\hline $\begin{array}{l}\text { Sim, de } \\
\text { todos os } \\
\text { brasileiros }\end{array}$ & 66 & 66 & 65 & 68 & 65 & 65 & 64 & 66 & 66 & 71 & 68 & 62 & 57 \\
\hline $\begin{array}{c}\text { Sim, só } \\
\text { dos mais } \\
\text { ricos }\end{array}$ & 2 & 2 & 1 & 1 & 1 & 2 & 2 & 2 & 3 & 1 & 1 & 2 & 0 \\
\hline $\begin{array}{c}\text { Sim, só } \\
\text { dos mais } \\
\text { pobres }\end{array}$ & 28 & 28 & 28 & 26 & 30 & 29 & 29 & 25 & 27 & 24 & 27 & 32 & 38 \\
\hline $\begin{array}{c}\text { De } \\
\text { ninguém }\end{array}$ & 2 & 2 & 2 & 2 & 1 & 2 & 2 & 2 & 1 & 2 & 2 & 3 & 1 \\
\hline NS/NR & 3 & 2 & 3 & 2 & 2 & 2 & 2 & 45 & 4 & 3 & 2 & 2 & 3 \\
\hline
\end{tabular}

Fonte: elaborado pelo autor com base em IPMN (2010).

Tabela 6 - Opinião sobre o presidente Lula haver melhorado a vida dos brasileiros (\%)

\begin{tabular}{|c|c|c|c|c|c|c|c|c|c|c|c|c|}
\hline & & \multicolumn{5}{|c|}{ Renda } & \multicolumn{6}{|c|}{ Região de desenvolvimento } \\
\hline & Total & $\begin{array}{c}\text { Até } \\
1 \\
\text { SM }\end{array}$ & $\begin{array}{l}\text { Acima } \\
\text { de } 1 \text { a } \\
2 \text { SM }\end{array}$ & $\begin{array}{c}\text { Acima } \\
\text { de } 2 \text { a } \\
5 \text { SM }\end{array}$ & $\begin{array}{c}\text { Acima } \\
\text { de } 5 \\
\text { SM }\end{array}$ & NS/NR & Recife & $\begin{array}{l}\text { RMR } \\
\text { exceto } \\
\text { Recife }\end{array}$ & $\begin{array}{c}\text { Zona } \\
\text { da } \\
\text { mata }\end{array}$ & Agreste & Sertão & $\begin{array}{l}\text { Reg. São } \\
\text { Francisco }\end{array}$ \\
\hline Base & 100 & 58 & 26 & 7 & 2 & 8 & 18 & 24 & 15 & 24 & 10 & 10 \\
\hline $\begin{array}{l}\text { Sim, de } \\
\text { todos os } \\
\text { brasileiros }\end{array}$ & 66 & 66 & 65 & 68 & 62 & 68 & 67 & 63 & 72 & 63 & 65 & 68 \\
\hline $\begin{array}{l}\text { Sim, só } \\
\text { dos mais } \\
\text { ricos }\end{array}$ & 2 & 1 & 2 & 2 & 3 & 2 & 2 & 2 & 2 & 2 & 0 & 1 \\
\hline $\begin{array}{c}\text { Sim, só } \\
\text { dos mais } \\
\text { pobres }\end{array}$ & 28 & 28 & 30 & 27 & 33 & 25 & 26 & 31 & 21 & 31 & 31 & 27 \\
\hline $\begin{array}{c}\text { De } \\
\text { ninguém }\end{array}$ & 2 & 2 & 1 & 3 & 3 & 1 & 2 & 1 & 2 & 2 & 1 & 2 \\
\hline NS/NR & 3 & 3 & 2 & 0 & 0 & 4 & 2 & 5 & 3 & 2 & 2 & 2 \\
\hline
\end{tabular}

Fonte: elaborado pelo autor com base em IPMN (2010).

Caso Lula venha a ser candidato a presidente pelo PSDB ou PMDB, e não pelo PT, você votará nele? Afirmam que sim 93\%. Esse percentual é semelhante em todos os estratos econômicos e regiões. Constatamos, portanto, que independentemente do partido, o presidente Lula tem o apreço do eleitor pernambucano. Além disso, verificamos que a figura do presidente Lula, e, claro, o lulismo, não depende das agremiações partidárias para existir e se manifestar. Enfim, o lulismo está acima dos partidos políticos, e reforça e torna mais nítido o personalismo na competição eleitoral do Brasil.

${ }^{20}$ Pergunta: O governo do presidente Lula melhorou a vida dos brasileiros? 
Tabela 7 - Opinião sobre votar em Lula para presidente como candidato do PSDB ou PMDB $^{21}(\%)$

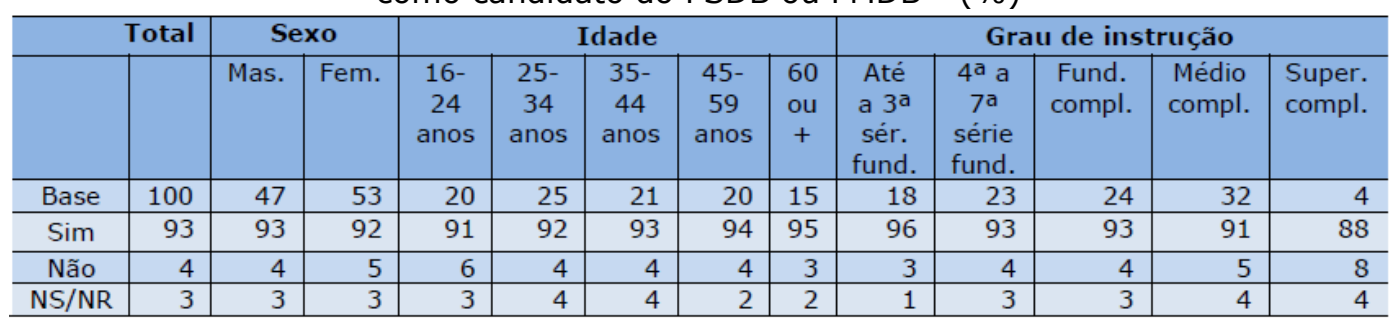

Fonte: elaborado pelo autor com base em IPMN (2010).

Tabela 8 - Opinião sobre votar em Lula para presidente como candidato pelo PSDB ou PMDB (\%)

\begin{tabular}{c|c|c|c|c|c|c|c|c|c|c|c|c}
\hline \multicolumn{1}{|c|}{ Total } & \multicolumn{9}{c|}{ Renda } & \multicolumn{6}{c}{ Região de desenvolvimento } \\
\hline & & $\begin{array}{c}\text { Até } \\
1 \\
\text { SM }\end{array}$ & $\begin{array}{c}\text { Acima } \\
\text { de 1 } \\
\text { a 2 } \\
\text { SM }\end{array}$ & $\begin{array}{c}\text { Acima } \\
\text { de 2 } \\
\text { a 5 } \\
\text { SM }\end{array}$ & $\begin{array}{c}\text { Acima } \\
\text { de 5 } \\
\text { SM }\end{array}$ & NS/NR & Recife & $\begin{array}{c}\text { RMR } \\
\text { exceto } \\
\text { Recife }\end{array}$ & $\begin{array}{c}\text { Zona } \\
\text { da } \\
\text { mata }\end{array}$ & $\begin{array}{c}\text { Agreste } \\
\text { Sertão }\end{array}$ & $\begin{array}{c}\text { Reg. São } \\
\text { Francisco }\end{array}$ \\
\hline Base & 100 & 58 & 26 & 7 & 2 & 8 & 18 & 24 & 15 & 24 & 10 & 10 \\
\hline Sim & 93 & 92 & 94 & 90 & 97 & 93 & 92 & 92 & 96 & 95 & 96 & 83 \\
\hline Não & 4 & 5 & 4 & 5 & 3 & 3 & 7 & 5 & 2 & 3 & 0 & 8 \\
\hline NS/NR & 3 & 3 & 2 & 5 & 0 & 4 & 1 & 3 & 2 & 2 & 4 & 9 \\
\hline
\end{tabular}

Fonte: elaborado pelo autor com base em IPMN (2010).

Você se considera uma pessoa de esquerda, centro esquerda, centro, centro direita, direita? Afirmam que são de esquerda $11,3 \%$; centro esquerda $3,2 \%$; centro $2,1 \%$; centro direita $0,4 \%$; de direita $18,1 \%$; sem posição ideológica $33,5 \%$ e $31,4 \%$ não souberam/não responderam. Os dados revelam que $64,9 \%$ não se autodefinem ideologicamente.

${ }^{21}$ Pergunta: Caso Lula venha a ser candidato a presidente pelo PSDB ou PMDB, e não pelo PT, você votará nele? 
Figura 7 - Gráfico representativo da posição ideológica do entrevistado ${ }^{22}$ (\%)

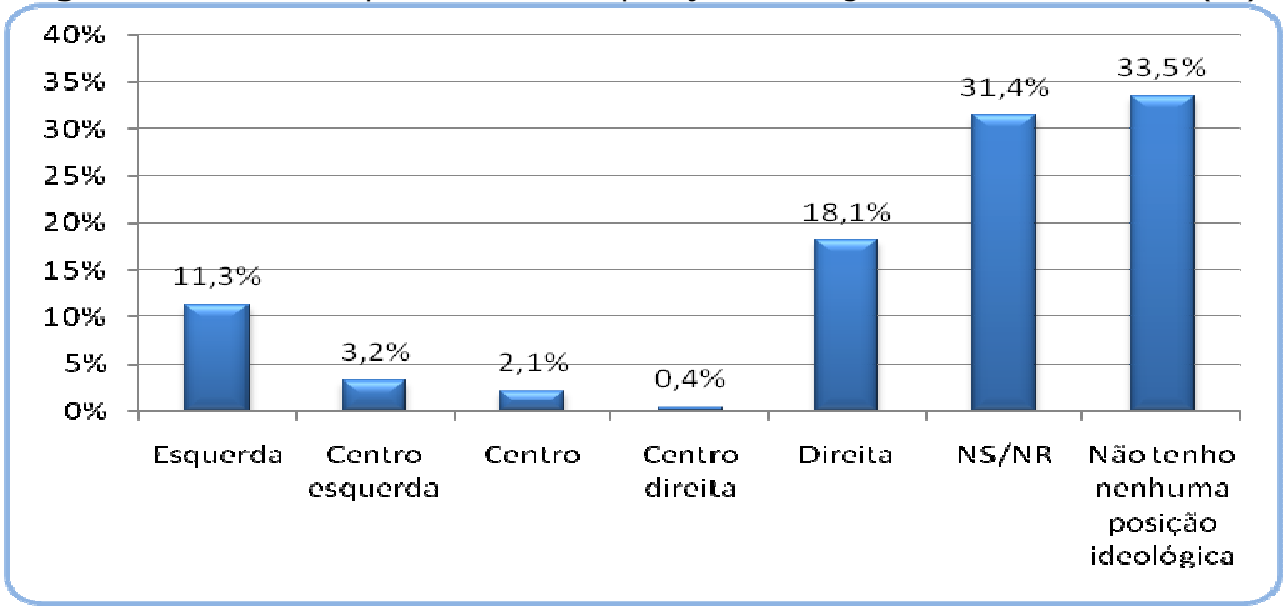

Fonte: elaborado pelo autor com base em IPMN (2010).

Utilizando o teste estatístico do qui-quadrado $\left(\chi^{2}\right)$, procuramos verificar se existe associação entre ideologia e outras variáveis. 0 teste qui-quadrado testa se uma distribuição de frequências observadas difere significativamente de outra distribuição observada. Ele busca, portanto, analisar o relacionamento entre variáveis categóricas (LEVIN e FOX, 2004; DANCEY e REIDY, 2006).

Adiante, buscamos responder à seguinte indagação: a frequência da variável $X$ está associada à frequência da variável ideologia? Ou melhor: as variáveis $X, Y, Z(\ldots)$ estão associadas à variável ideologia? Quando o $p$-valor é menor de 0,05 estamos diante de associação entre duas variáveis.

Com o objetivo de facilitar a realização do referido teste, agrupamos as categorias centro esquerda, centro direita e centro numa só, e desconsideramos as categorias Não sabe/Não respondeu e Não tenho nenhuma posição ideológica.

A Tabela 9 revela, por meio do teste do qui-quadrado $\left(\chi^{2}\right)$, associação significativa entre as variáveis Para você qual foi o melhor presidente da história do Brasil e Você se considera uma pessoa de esquerda, centro esquerda, centro, centro direita ou direita? ao nível de $5 \%$ de significância. Além disso, os dados mostram que a variável ideologia não interfere na opinião dos eleitores quanto a quem foi o melhor presidente do Brasil.

22 Você se considera uma pessoa de esquerda, centro esquerda, centro, centro direita ou direita? 
Tabela 9 - Opinião sobre quem foi o melhor presidente da história do Brasil versus Posição ideológica do entrevistado (\%)

\begin{tabular}{|c|c|c|c|c|}
\hline \multirow{2}{*}{$\begin{array}{c}\text { Para você, qual foi } \\
\text { o melhor } \\
\text { presidente da } \\
\text { história do Brasil? }\end{array}$} & \multicolumn{3}{|c|}{$\begin{array}{l}\text { Você se considera uma pessoa de esquerda, direita, } \\
\text { centro, centrodireita ou centroesquerda? }\end{array}$} & \multirow{2}{*}{ Total } \\
\hline & Esquerda & $\begin{array}{l}\text { Centro/Centroesquerda/ } \\
\text { Centrodireita }\end{array}$ & Direita & \\
\hline Lula & 96,3 & 90,6 & 91,6 & 92,9 \\
\hline Outros presidentes & 3,7 & 9,4 & 8,4 & 7,1 \\
\hline Total & 100 & 100 & 100 & 100 \\
\hline
\end{tabular}

Encontramos resultados semelhantes nas Tabelas 10, 11, 12 e 13 que se seguem. Isto é: a posição ideológica do indivíduo está associada à opinião dos eleitores quanto ao presidente Lula. Não observamos variações abruptas dos percentuais por categorias.

Tabela 10 - Opinião sobre o presidente do Brasil que mais fez por Pernambuco versus Posição ideológica do entrevistado (\%)

\begin{tabular}{|c|c|c|c|c|}
\hline \multirow{2}{*}{$\begin{array}{c}\text { Para você, qual foi o } \\
\text { presidente que mais } \\
\text { fez por } \\
\text { Pernambuco? }\end{array}$} & \multicolumn{3}{|c|}{$\begin{array}{l}\text { Você se considera uma pessoa de esquerda, direita, } \\
\text { centro, centrodireita ou centroesquerda? }\end{array}$} & \multirow{2}{*}{ Total } \\
\hline & Esquerda & $\begin{array}{l}\text { Centro/Centroesquerda/ } \\
\text { Centrodireita }\end{array}$ & Direita & \\
\hline Lula & 99,6 & 97,1 & 96,8 & 97,8 \\
\hline Outros presidentes & 0,4 & 2,9 & 3,2 & 2,2 \\
\hline Total & 100 & 100 & 100 & 100 \\
\hline
\end{tabular}

Tabela 11 - Avaliação da administração do presidente Lula versus Posição ideológica do entrevistado (\%)

\begin{tabular}{c|c|c|c|c}
\hline \multirow{2}{*}{$\begin{array}{c}\text { Qual é sua avaliação da } \\
\text { administração do } \\
\text { presidente Lula? }\end{array}$} & \multicolumn{2}{|c|}{$\begin{array}{c}\text { Você se considera uma pessoa de esquerda, } \\
\text { direita, centro, centro-direita ou centro- } \\
\text { esquerda? }\end{array}$} & Total \\
\cline { 2 - 5 } & Esquerda & $\begin{array}{c}\text { Centro/Centro-esquerda/ } \\
\text { Centro-direita }\end{array}$ & Direita & \\
\hline Ótima & 69,8 & 66,4 & 58,9 & 63,6 \\
\hline Boa & 27,3 & 28,6 & 35,1 & 31,5 \\
\hline Regular/Ruim/Péssima & 2,9 & 5,0 & 100 & 100 \\
\hline Total & 100 & 100 & 6,9 \\
\hline
\end{tabular}

Fonte: elaborado pelo autor com base em IPMN (2010). $\quad p$-valor $=0,030$ 
Tabela 12 - Opinião sobre Lula ser candidato novamente a presidente da República em 2014 versus Posição ideológica do entrevistado (\%)

\begin{tabular}{|c|c|c|c|c|}
\hline \multirow{2}{*}{$\begin{array}{l}\text { O presidente Lula findará o } \\
\text { mandato este ano. Em sua } \\
\text { opinião, ele merece ser } \\
\text { candidato novamente à } \\
\text { Presidência na eleição de } \\
2014 ?\end{array}$} & \multicolumn{3}{|c|}{$\begin{array}{l}\text { Você se considera uma pessoa de esquerda, } \\
\text { direita, centro, centrodireita ou } \\
\text { centroesquerda? }\end{array}$} & \multirow{2}{*}{ Total } \\
\hline & Esquerda & $\begin{array}{c}\text { Centro/Centroesquerda/ } \\
\text { Centrodireita }\end{array}$ & Direita & \\
\hline Sim & 95,3 & 94,0 & 92,9 & 93,8 \\
\hline Não & 4,7 & 6,0 & 7,1 & 6,2 \\
\hline Total & 100 & 100 & 100 & 100 \\
\hline
\end{tabular}

Tabela 13 - Opinião sobre o presidente Lula haver melhorado a vida dos brasileiros versus Posição ideológica do entrevistado (\%)

\begin{tabular}{c|c|c|c|c}
\hline \multirow{2}{*}{$\begin{array}{c}\text { O governo do } \\
\text { presidente Lula } \\
\text { melhorou a vida dos } \\
\text { brasileiros }\end{array}$} & \multicolumn{2}{|c|}{$\begin{array}{c}\text { Você se considera uma pessoa de esquerda, direita, } \\
\text { centro, centrodireita ou centroesquerda? }\end{array}$} & \multirow{2}{*}{ Total } \\
\cline { 2 - 5 } & Esquerda & $\begin{array}{c}\text { Centro/Centroesquerda/ } \\
\text { Centrodireita }\end{array}$ & Direita & \\
\hline $\begin{array}{c}\text { Sim, de todos os } \\
\text { brasileiros }\end{array}$ & 72,9 & 78,3 & 67,2 & 70,8 \\
\hline Só dos mais ricos & 1,1 & 2,2 & 1,1 & 1,3 \\
\hline Só dos mais pobres & 25,3 & 15,2 & 29,4 & 25,8 \\
\hline De ninguém & 0,7 & 4,3 & 2,3 & 2,1 \\
\hline Total & 100 & 100 & 100 & 100 \\
\hline
\end{tabular}

Fonte: elaborado pelo autor com base em IPMN (2010). $\quad p$-valor $=0,008$

Os dados revelam, com o auxílio da Figura 8 , que os eleitores pernambucanos, independentemente da posição ideológica, têm majoritariamente opiniões positivas quanto ao presidente Lula.

Figura 8 - Gráfico representativo da posição ideológica e outras variáveis

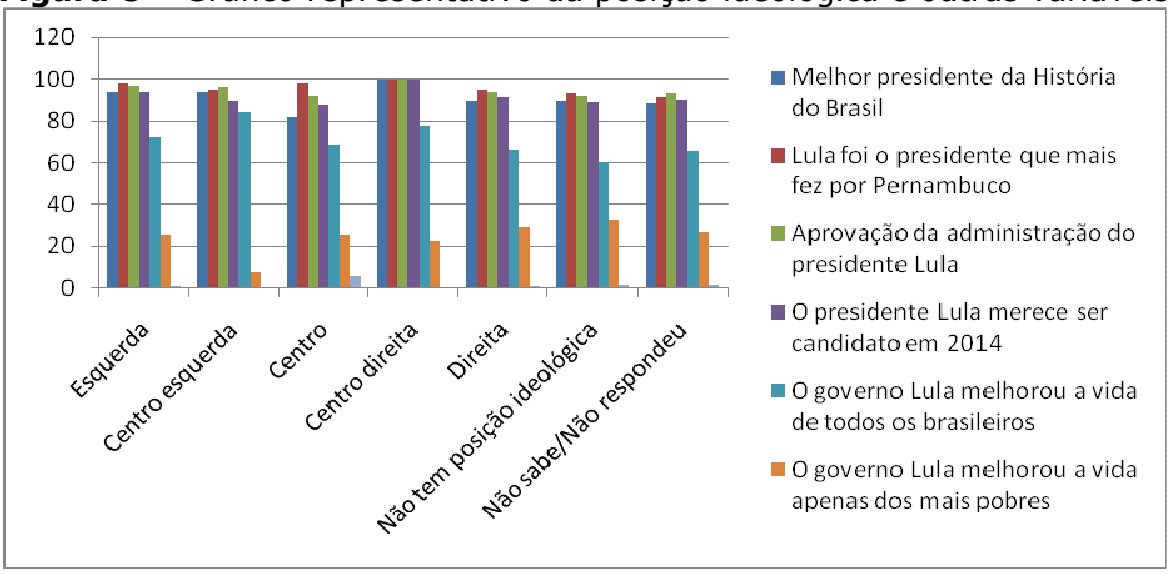

Fonte: elaborado pelo autor com base em IPMN (2010). 


\section{Conclusão}

Considerando a literatura e os dados apresentados, concluímos que o bem-estar econômico dos brasileiros contribuiu - à parte outros fatores não abordados neste artigo - para a avaliação pujante da administração do presidente Lula e o elevado índice de confiança nele depositado. Carreirão (2009) corrobora com essa assertiva ao explicar o sucesso eleitoral de Lula na disputa presidencial de 2006.

As variáveis Avaliação da Administração e Confiança expressam a manifestação do lulismo no eleitorado. Em dado momento da gestão Lula, os eleitores, conforme já mostrado, ficaram reticentes quanto à avaliação da administração do presidente Lula e se nele deveriam confiar em virtude de circunstâncias políticas.

Contudo, após o escândalo do mensalão, a aprovação à administração do presidente Lula cresceu igualmente à confiança em sua pessoa. Nesse sentido, conforme propõe Pimentel Júnior (2007 e 2010), em determinado momento, os eleitores ficaram emocionalmente reticentes em aprovar fortemente o governo Lula e em nele confiar.

Entretanto, após o arrefecimento da repercussão do mensalão na opinião pública, a crença e a expectativa em parceria com o crescimento econômico contribuíram para que sentimentos de entusiasmo florescessem no eleitorado, o que favoreceu o aumento da aprovação à administração do presidente Lula e do percentual de eleitores que nele confiam.

Este artigo mostrou que o fenômeno social lulismo teve início no primeiro mandato do presidente Lula. Porém, diante do escândalo do mensalão, a construção do lulismo foi interrompida ou enfraquecida. Após o escândalo, o embrião do lulismo recrudesceu, o que é verificável, como já dito, nos índices de aprovação à administração e da confiança. Com o fim da eleição presidencial de 2006, iniciou-se o processo de consolidação do lulismo, chegando a seu ápice no fim do mandato do presidente Lula.

Os dados de diversos indicadores revelaram que o lulismo, independentemente da posição ideológica e do estrato econômico do eleitor, existe em Pernambuco, onde é um fenômeno social que reforça o personalismo na política e enfraquece os partidos políticos.

O lulismo deve ser considerado como um novo determinante do voto para explicar a escolha do eleitor em virtude de que: 1) sua conceituação é possível com a utilização dos determinantes clássicos que explicam a escolha do eleitor - avaliação da administração, bem-estar econômico e emoção (confiança); 2) $91 \%$ dos pernambucanos, conforme mostrado, afirmaram que o presidente Lula merece ser candidato na disputa presidencial de 2014.

Nesse sentido, temos a hipótese de que se os indicadores Avaliação da Administração e Confiança, além de outros mostrados, mantiverem-se estáveis na mente dos eleitores, o ex-presidente Lula poderá ser candidato competitivo na disputa presidencial de 2014 ou um apoio eleitoral de peso. 


\section{ARTIGOS}

Porém, não se deve desprezar a ação das circunstâncias políticas e econômicas, e o desempenho eleitoral de diversos atores, uma vez que as consequências delas podem possibilitar 0 fortalecimento ou 0 enfraquecimento do capital eleitoral do ex-presidente Lula no período 20112014. Neste momento, portanto, a questão que este artigo sugere é: por quanto tempo o fenômeno social lulismo se manterá vivo e pujante na cabeça dos eleitores?

Adriano Oliveira é Doutor em Ciência Política, Professor Adjunto do Departamento de Ciência Política da UFPE, Coordenador do Núcleo de Estudos de Estratégias e Política Eleitoral da UFPE e Membro do Núcleo de Estudos de Instituições Coercitivas da UFPE.

E-mail: adrianopolitica@uol.com.br

\section{Referências:}

ACIMA das expectativas, Lula encerra mandato com melhor avaliação da história. Datafolha Opinião pública, 20 dez. 2010. Disponível em: <http://datafolha.folha.uol.com.br/po/ver_po.php?session=1122>. Acesso em: 02 fev. 2011.

ALMEIDA, Alberto Carlos. A cabeça do eleitor. São Paulo: Record, 2008.

AOKI, Masahiko. Endogenizing institutions and institutional changes. Journal of Institutional Economics, Hartfield, v. 3, n. 1, p. 1-31, 2007.

BORBA, Julian. Cultura política, ideologia e comportamento eleitoral: alguns apontamentos teóricos sobre o caso brasileiro. Opinião Pública, Campinas, v. 11, n. 1, p. 147-168, mar. 2005.

BOUDON, Raymond (Org.). Tratado de sociologia. Rio de Janeiro: Jorge Zahar, 1995.

CARREIRÃO, Yan de Souza. A decisão do voto nas eleições presidenciais brasileiras. Rio de Janeiro: Fundação Getúlio Vargas, 2002.

La elección presidencial brasileña de 2006: voto económico y clivajes sociales. In: BRAUN, Maria; STRAW, Cecília (Orgs.). Opinion Pública: una mirada desde América Latina. Buenos Aires: Emecé, 2009. p. 35-52.

DANCEY, Christine P.; REIDY, John. Estatística sem matemática para psicologia: usando SPSS para Windows. 3. ed. Porto Alegre: Artmed, 2006.

DARTIGUES, André. O que é a fenomenologia? São Paulo: Centauro, 2008. 
ELSTER, Jon. Egonomics: análisis de la interacción entre racionalidad, emoción preferencias y normas sociales en la economia de la acción individual y sus desviaciones. Barcelona: Gedisa, 1997.

. El cambio tecnológico: investigaciones sobre la racionalidad y la transformación social. 5. ed. Barcelona: Gedisa, 2006.

EPAMINONDAS NETO. Lula nega "mensalão", mas admite caixa dois no PT. Folha online, 8 nov. 2005. Disponível em: <http://www1.folha.uol.com.br/folha/brasil/ult96u73772.shtml>. Acesso em: 25 jan. 2011.

FIORINA, Morris. Retrospective voting in American national elections. New Haven: Yale University Press, 1981.

IBOPE: confiança no presidente. 2010. Uol Notícias, 2010. Disponível em: <http://noticias.uol.com.br/fernandorodrigues/arquivos/pesquisas/ibope/lulaconfianca.jhtm>. Acesso em: 04 fev. 2011.

IPEA. IPEADATA. Disponível em: <http://www.ipeadata.gov.br/>. Acesso em: 28 fev. 2011.

IPMN. Instituto de Pesquisa Mauricio de Nassau. Recife, 2010. Disponível em: < http://www.institutomauriciodenassau.com.br/blog/>. Acesso em: $28 \mathrm{fev}$. 2011.

LACERDA, Angela. Lula "está acima do bem e do mal", diz José Serra. $O$ Estado de São Paulo, 13 maio 2010. Disponível em: <http://www.estadao.com.br/noticias/nacional,lula-esta-acima-do-bem-e-domal-diz-jose-serra,551374,0.htm>. Acesso em: 02 fev. 2011.

LAVAREDA, Antonio. Emoções ocultas e estratégias eleitorais. Rio de Janeiro: Ed. Objetiva, 2009.

LEVIN, Jack; FOX, James Alan. Estatística para ciências humanas. 9. ed. São Paulo: Prentice Hall, 2004.

LOURENÇO, Luiz Cláudio. Abrindo a caixa-preta: da indecisão à escolha a eleição presidencial de 2002. 2007. 319 f. Tese (Doutorado em Ciências Políticas e Sociologia) - Instituto Universitário de Pesquisas do Rio de Janeiro, Rio de Janeiro, [2007].

MARCUS, George. The Psychology of Emotions and Politics. In: SEARS, David O.; HUDDY, Leonie; JERVIS, Robert (Orgs.). Oxford Handbook of Political Psychology. Oxford: Oxford University Press, 2003. p. 182-221. 
OLIVEIRA, Adriano; SANTOS, Roberto. Boas administrações elegem candidatos?: uma análise do comportamento dos eleitores em sete capitais brasileiras nas eleições de 2008. Revista Debates, Porto Alegre, v. 3, n. 2, p. 116-138, jul.-dez. 2009.

PEREIRA, Merval. O lulismo no poder. Rio de Janeiro: Record, 2010.

PIMENTEL JÚNIOR, Jairo Tadeu Pires. Razão e emoção: o voto na eleição presidencial de 2006. 2007. 129 f. Dissertação (Mestrado em Ciência Política) - Programa de Pós-Graduação em Ciência Política, Departamento de Ciência Política, Faculdade de Filosofia, Letras e Ciências Humanas, Universidade de São Paulo, São Paulo [2007].

Razão e emoção: o voto na eleição presidencial de 2006. Opinião Pública, Campinas, v. 16, n. 2, p. 516-541, nov. 2010.

REZENDE, Cláudia Barcellos; COELHO, Maria Cláudia Pereira. Antropologia das emoções. Rio de Janeiro: FGV, 2010.

REZENDE, Flávio. Analytical challenges for neoinstitucional theories of institucional change in comparative political science. Brazilian Political Science Review, Rio de Janeiro, v. 3, n. 2, p. 98-126, jul.-dec. 2009.

RICCI, Rudá. Lulismo: da era dos movimentos sociais à ascensão da nova classe média brasileira. Brasília: Fundação Astrojildo Pereira/Contraponto, 2010.

SARTORI, Giovanni. A política. 2. ed. Brasília: Universidade de Brasília, 1997.

SINGER, André. Raízes sociais e ideológicas do lulismo. Novos Estudos CEBRAP, São Paulo, n. 85, p. 83-102, nov. 2009. Disponível em: <http://novosestudos.uol.com.br/acervo/acervo_artigo.asp?idMateria=1356> . Acesso em: 14 fev. 2010.

VAN EVERA, Stephen. Guide to methods for students of political science. New York: Cornell University, 1997.

WESTEN, Drew. O cérebro político. São Paulo: Unianchieta, 2007.

Texto recebido em 16/05/2011. Aprovado em 07/06/2011. 